\title{
Itch and skin rash from chocolate during fluoxetine and sertraline treatment: Case report Jonas Cederberg*1, Stefan Knight ${ }^{2}$, Svante Svenson ${ }^{3}$ and Håkan Melhus ${ }^{1}$
}

\author{
Address: ${ }^{1}$ Department of Clinical Chemistry and Pharmacology, Uppsala Academic Hospital, Uppsala, Sweden, ${ }^{2}$ Department of Molecular \\ Biology, Swedish University of Agricultural Sciences, Uppsala, Sweden and ${ }^{3}$ Fålhagens Primary Care Center, Uppsala, Sweden \\ Email: Jonas Cederberg* - jonas.cederberg@medsci.uu.se; Stefan Knight - stefan@xray.bmc.uu.se; Svante Svenson - svante.svenson@lul.se; \\ Håkan Melhus - hakan.melhus@medsci.uu.se \\ * Corresponding author
}

Published: 02 November 2004

BMC Psychiatry 2004, 4:36 doi:10.1 186/147|-244X-4-36
Received: 18 May 2004

Accepted: 02 November 2004

This article is available from: http://www.biomedcentral.com/I47I-244X/4/36

(C) 2004 Cederberg et al; licensee BioMed Central Ltd.

This is an Open Access article distributed under the terms of the Creative Commons Attribution License (http://creativecommons.org/licenses/by/2.0), which permits unrestricted use, distribution, and reproduction in any medium, provided the original work is properly cited.

\begin{abstract}
Background: The skin contains a system for producing serotonin as well as serotonin receptors. Serotonin can also cause pruritus when injected into the skin. SSRI-drugs increase serotonin concentrations and are known to have pruritus and other dermal side effects.

Case presentation: A 46-year-old man consulted his doctor due to symptoms of depression. He did not suffer from any allergy but drinking red wine caused vasomotor rhinitis. Antidepressive treatment with fluoxetine $20 \mathrm{mg}$ daily was initiated which was successful. After three weeks of treatment an itching rash appeared. An adverse drug reaction (ADR) induced by fluoxetine was suspected and fluoxetine treatment was discontinued. The symptoms disappeared with clemastine and betametasone treatment. Since the depressive symptoms returned sertraline medication was initiated. After approximately two weeks of sertraline treatment he noted an intense itching sensation in his scalp after eating a piece of chocolate cake. The itch spread to the arms, abdomen and legs and the patient treated himself with clemastine and the itch disappeared. He now realised that he had eaten a chocolate cake before this episode and remembered that before the first episode he had had a chocolate mousse dessert. He had never had any reaction from eating chocolate before and therefore reported this observation to his doctor.
\end{abstract}

Conclusions: This case report suggests that there may be individuals that are very sensitive to increases in serotonin concentrations. Dermal side reactions to SSRI-drugs in these patients may be due to high activity in the serotonergic system at the dermal and epidermo-dermal junctional area rather than a hypersensitivity to the drug molecule itself.

\section{Background}

The skin contains a system for producing serotonin as well as serotonin receptors. Serotonin can also cause pruritus when injected into the skin. SSRI-drugs increase serotonin concentrations and are known to have pruritus and other dermal side effects e.g. exanthema, purpura, urticaria and pruritus [1]. In contrast, SSRI-medication has also been used to treat pruritus associated with cholestasis [2] and polycythemia vera [3]. In this report we describe a patient who developed pruritus and skin rash from chocolate, but only when he was under SSRI-treatment. The case is presented and we provide a putative biological rationale for the described phenomenon. 


\section{Case presentation}

A 46-year-old man consulted his doctor in September 2003 due to depression. He had then experienced symptoms for a few years that had aggravated during the last six to eight months. Using the Montgomery-Åsberg Depression Rate Scale (MADRS) the patient scored 24 points and was diagnosed as having a clinical depression. He did not take any medication and had no regular medical contact. The patient did not have any history of allergy or dermatological diseases. However, he sometimes suffered from vasomotor rhinitis after drinking red wine. The doctor prescribed fluoxetine $20 \mathrm{mg}$ daily as antidepressive treatment. At the revisit three weeks later the patient was very pleased with the fluoxetine treatment and reported that he "had not felt better in 20 years" although he initially had experienced slight nausea and insomnia.

A week later, he visited his doctor due to an itching rash that had started the day before. The doctor noted partly confluent urticae on the abdomen, a modest periorbital oedema and red, warm palms and wrists. An ADR induced by fluoxetine was suspected and fluoxetine treatment was discontinued. The symptoms were treated with $2 \mathrm{mg}$ clemastine and $6 \mathrm{mg}$ betametasone orally and disappeared within 48 hours. However, the symptoms of depression returned. Sertraline medication was initiated 10 days after the cessation of fluoxetine treatment since SSRI medication had shown good effect. During the weeks of sertraline treatment no urticarial symptoms appeared. The patient improved in his depression although full recovery was not achieved this time. After approximately two weeks of sertraline treatment he noted an intense itching sensation in his scalp after eating a piece of chocolate cake. The itch spread to the arms, abdomen and legs within a few hours. This time the patient did not seek his doctor but treated himself with clemastine and the itch disappeared during the night. He now remembered that he had had a chocolate mousse dessert before the first episode. Since he had never had any reaction from eating chocolate before, he found this observation so striking that he reported it to his doctor. The patient, himself a scientist, later tried small doses of chocolate and skin rash and itch appeared at an intensity that to him seemed dependent on the "dose" of chocolate ingested.

It has been known for 30 years that serotonin can stimulate cutaneous C-fibres [4], the type of fibres that is also known to transmit itch [5]. Moreover, serotonin injections into the skin can induce itch [6] and pruritus is a component in $24 \%$ of reported skin reactions to fluoxetine in Sweden, the corresponding figure for sertraline is 15 $\%$ [1]. However, attempts to treat pruritus using 5-HT3receptor-antagonists have not given clear-cut results [6-8]. The enzymes necessary for conversion of tryptophan to serotonin are expressed in human skin [9]. In addition, 5-
HT2AR are present in one third of unmyelinated axons at the dermal and epidermo-dermal junctional area [10]. An altered localisation pattern of serotonin receptors 5HT1AR, 5-HT2AR and 5-HT3R has been reported in contact eczematous skin together with increased serotonin concentrations $[11,12]$ indicating the presence of a serotonin system in the skin that can be altered in pathologic conditions. Moreover, a cross-sensitivity has been reported when skin rash developed after both paroxetine and sertraline medication [13]. Since these substances are structurally different, one interpretation is that the skin can react to an SSRI-induced increase in serotonin concentrations.

In the present case the patient experienced skin symptoms from two different SSRIs. However, these symptoms occurred only when he had eaten chocolate. Chocolate contains serotonin, at concentrations which depend on the type of chocolate [14]. A concentration of $1.4-5 \mu \mathrm{g} /$ $\mathrm{g}$ has been reported in dark chocolate [14]. The present report suggests an interaction between SSRI-medication and chocolate leading to pruritus and rash. A plausible explanation is that SSRI together with serotonin-containing chocolate has increased serotonin concentration to a level where 5-HT receptors system at the dermal and epidermo-dermal junctional area are affected. Moreover, the patient in this case had previously noted nasal congestion and cough when he was drinking red wine. Red wine can induce release of serotonin from platelets [15] and from the gut [16]. Serotonin can induce nasal itch, sneeze and hypersecretion $[17,18]$.

\section{Conclusions}

Apart from the SSRI - chocolate interaction this patient had another possible sign of sensitivity to serotonin. The present case thus suggests that there may be individuals that are very sensitive to increases in serotonin concentrations. Skin side reactions to SSRI-drugs in these patients may be due to high activity in the serotonergic system system at the dermal and epidermo-dermal junctional area rather than a hypersensitivity to the drug molecule itself. However, the reaction of skin to serotonin from food is poorly studied and further studies are necessary to determine how much alimentary serotonin can increase serum serotonin concentrations and to what extent SSRI-medication affects this process. More knowledge in this field could be of help for physicians who encounter patients with dermal reactions to SSRI-drugs and there might be food and beverages containing serotonin that these patients should avoid. Moreover, possible individual differences in the serotonergic system at the dermal-epidermal junction remain to be studied.

What happened to the patient and his depression? Due to poor anti-depressive effect of sertraline, the treatment was 
altered back to fluoxetine. He is now free from his depression and experiences no rash or oedema-like adverse reactions as long as he is avoiding chocolate.

\section{List of abbreviations}

5-HT: 5-hydroxytryptamine, ADR: Adverse Drug Reaction, SSRI: serotonin selective reuptake inhibitors

\section{Competing interests}

The author(s) declare that they have no competing interests.

\section{Authors' contributions}

SS first described the case, JC and HM performed literature searches and JC first drafted the manuscript. HM and SK took part in the scientific discussion and in finalising the manuscript.

\section{Acknowledgements}

Written consent was obtained from the patient for publication of study.

\section{References}

I. SWEDIS, the Swedish Drug Information System database.

2. Browning J, Combes B, Mayo MJ: Long-term efficacy of sertraline as a treatment for cholestatic pruritus in patients with primary biliary cirrhosis. Am / Gastroenterol 2003, 98:2736-4I.

3. Tefferi A, Fonseca R: Selective serotonin reuptake inhibitors are effective in the treatment of polycythemia vera-associated pruritus. Blood 2002, 99:2627.

4. Beck PW, Handwerker HO: Bradykinin and serotonin effects on various types of cutaneous nerve fibres. Pflugers Arch 1974, 347:209-22.

5. Schmeltz M, Schmidt R, Bickel A, Handwerker HO, Torebjörk HE: Specific C-receptors for itch in human skin. J Neuosci 1997, 17:8003-08

6. Weisshaar E, Ziethen B, Gollnick H: Can a serotonin type 3 (5HT3) receptor antagonist reduce experimentally-induced itch? Inflamm Res 1997, 46:412-16.

7. Ashmore SD, Jones CH, Newstead CG, Daly MJ, Chrystyn H: Ondansetron therapy for uremic pruritus in hemodialysis patients. Am J Kidney Dis 2000, 35:827-31.

8. Schwörer H, Hartmann H, Ramadori G: Relief of cholestatic pruritus by a novel class of drugs: 5-hydroxytryptamine type 3 (5-HT3) receptor antagonists: effectiveness of ondansetron. Pain 1995, 61:33-37.

9. Slominski A, Pisarchik A, Semak I, Sweatman T, Wortsman J, Szczesniewski A, Slugocki G, McNulty J, Kauser S, Tobin DJ, Jing C, Johansson $\mathrm{O}$ : Serotonergic and melatoninergic systems are fully expressed in human skin. FASEB J 2002, 16:896-98.

10. Carlton SM, Coggeshall RE: Immunohistochemical localization of 5-HT2A receptors in peripheral sensory axons in rat glabrous skin. Brain Res 1997, 763:27I-75.

II. Lundeberg L, El-Nour, Mohabbatti S, Morales M, Azmitia E, Nordlind $\mathrm{K}$ : Expression of serotonin receptors in allergic contact excematous human skin. Arch Dermatol Res 2002, 294:393-98.

12. Lundeberg L, Liang Y, Sundström E, Nordlind K, Verhofstad A, Liden $S$, Johansson O: Serotonin in human allergic contact dermatitis. An immunohistochemical and high performance liquid chromatography study. Arch Dermatol Res 1999, 29 I:269-74.

13. Warnock CA, Azadian AG: Cross-sensitivity between paroxetine and sertraline. Ann Pharmacother 2002, 36:63I-33.

14. Herraiz T: Tetrahydro-b-carbolines, potential neuroactive alkaloids, in chocolate and cocoa. J Agric Food Chem 2000, 48:4900-04.

15. Jarman J, Pattichis K, Peatfield R, Glover V, Sandler M: Red wineinduced release of $\left[{ }^{14} \mathrm{C}\right] 5$-hydroxytryptamine from platelets of migraine patients and controls. Cephalalgia 1996, 16:41-43.
16. Pattichis K, Louca L, Jarman J, Glover V: Red wine can cause a rise in human whole blood 5-hydroxytryptamine levels. Med $\mathrm{Sci}$ Res 1994, 22:38I-82.

17. Tonnesen $\mathrm{P}$, Mygind $\mathrm{N}$ : Nasal challenge with serotonin and histamine in normal persons. Allergy 1985, 40:350-53.

18. Tonnesen P, Schaffalitzky de Muckadell OB, Mygind N: Nasal challenge with serotonin in asymptomatic hay fever patients. Allergy 1987, 42:447-50.

\section{Pre-publication history}

The pre-publication history for this paper can be accessed here:

\section{http://www.biomedcentral.com/1471-244X/4/36/pre} pub
Publish with Bio Med Central and every scientist can read your work free of charge

"BioMed Central will be the most significant development for disseminating the results of biomedical research in our lifetime. "

Sir Paul Nurse, Cancer Research UK

Your research papers will be:

- available free of charge to the entire biomedical community

- peer reviewed and published immediately upon acceptance

- cited in PubMed and archived on PubMed Central

- yours - you keep the copyright 